\title{
Beata Antoszewska
}

Katedra Pedagogiki Specjalnej UWM w Olsztynie

\section{Aleksandra Tobota}

Instytut Matki i Dziecka w Warszawie

\section{Cisza i milczenie w obliczu dziecka $\mathrm{z}$ chorobą nowotworową - konieczność, naturalność czy klęska?}

\author{
Silence and remaining silent when facing a child with cancer - \\ necessity, naturalness or failure?
}

Silence and remaining silent occupy a significant position in human life. We need silence to think over many matters, and sometimes it is necessary to re-think them, especially considering modern civilization overwhelmed with noise, chaos, haste and overuse of words lacking meaning. We need silence to express our respect for human dignity by remaining silent. This article will first present a general understanding of silence and remaining silent. Then we will refer these notions to situations when a space of silence and remaining silent emerges around a child with cancer. The sources of such specific space will be indicated. Silence and remaining silent do not concern only the child itself, but also the child's relatives - parents and siblings, as well as all those individuals who come into contact with such a child. Silence and remaining silent when facing a child with cancer will be analyzed from various perspectives and dimensions, including diagnosis and treatment. For us, the most significant and at the same time the most unique situation is the one when silence and remaining silent embrace a child who cannot be cured and inevitably approaches death.In this paper we will attempt to answer a few key questions: Are silence and remaining silent a necessity or perhaps a natural reaction to the surrounding reality? Or, perhaps, their appearance is definitely unjustified. Maybe they should not accompany a child with cancer. Is it better or would it be better to speak or remain silent? And finally - where can the sources of such silence and remaining silent be found?

Słowa kluczowe: milczenie, trwanie/pozostawanie w milczeniu, dziecko z chorobą nowotworową Keywords: silence, remaining silent, child with cancer

\section{Wprowadzenie}

Cisza i milczenie to zjawiska towarzyszące człowiekowi od zawsze, choć różne były ich znaczenia i konteksty. Milczy się wówczas, kiedy nie chce się wypowia- 
dać słów, zabierać głosu w dyskusji, czyli chce się coś przemilczeć. Milczeć można wówczas, kiedy chcemy zaakcentować naszą emocjonalną reakcję na rzeczywistość. Świadome powstrzymywanie się od mówienia posiada wartość etyczną (np. dochowanie tajemnicy, trwanie wobec własnych wartości, ideałów) (Olearczyk 2010, s. 53). „O czym nie można mówić, o tym trzeba milczeć” pisał Ludwig Wittgenstein (Regiewicz, Żywiołek 2014, s. 11).

Milczeć można także, kiedy chce się zrozumieć, odnaleźć znaczenie wypowiadanego słowa, czyli coś przemyśleć. Powiadają „Cisza milczenia ustanawia znaczenie" (tamże, s. 12). Milczenie zasłania to czego wypowiedzieć nie można, nadaje temu sens. „Stosowany celowo brak słów wskazuje na dodatkowy sens, ale jest także odwrotnie - umiejętne posługiwanie się słowami otwiera wypowiedź na to, co pozostaje w sferze niewypowiedzianego" (Korwin-Piotrowska 2014, s. 36).

I w końcu można chcieć przekazać znaczenie, zakomunikować szacunek, dać wyraz pamięci lub zupełnie przeciwnie - wskazać na lekceważenie i obojętność.

Warto zaznaczyć, iż literatura nauk społecznych i humanistycznych ma bogatą reprezentację różnorodnych opracowań na temat ciszy i milczenia. Każda nauka, podkreślając odmienne aspekty wskazanych pojęć, przyczynia się do zbudowania pełnego ich obrazu. Językoznawstwo odnosi się do milczenia przede wszystkim jako zachowania komunikacyjnego. Psychologia interesuje się milczeniem w różnych zaburzeniach psychicznych. Pedagogika poszukuje drogi wykorzystania ciszy i milczenia $w$ wychowaniu.

Słowa "cisza” i "milczenie" w języku polskim, choć posiadają różny zakres znaczeniowy, są stosunkowo często stosowane zamiennie. Cisza to brak wszelkich odgłosów (milczenie); stan atmosfery bez wiatru lub z bardzo słabym powiewem; spokojne życie, bez niezwykłych wydarzeń i wstrząsów. To w końcu spokój wewnętrzny. Z kolei milczenie oznacza niemówienie, nieodzywanie się (cisza); brak reakcji na coś, niezabieranie głosu w jakiejś sprawie. Cisza jest następstwem milczenia, a milczenie wywołuje ciszę. Cisza może przejawiać się w milczeniu, w kontemplacji czy medytacji (Olearczyk 2010).

Milczeć można w hałasie. Cisza jednak wyklucza jego istnienie. Milczenie współtworzy ciszę, może w niej trwać. $Z$ kolei milczenie nie zawsze jest ciszą (tamże, s. 54). Milczenie, jak i cisza mogą prowadzić do uzyskania wiedzy niedostępnej za pomocą innych sposobów. Milczenie przekazuje wartości i pojęcia istniejące poza słowem (Niedziałkowski 1998, s. 16). „Milczenie może coś komunikować, ale wyłącznie w odpowiednim kontekście. Bez wyznaczającego ramy interpretacyjne kontekstu, milczenie jest tylko niemą ciszą" (Przybyszewski 2013).

Pośród wielu rodzajów milczenia jest i to, przypisywane ludziom, którzy już odeszli. Oni nie mają wyboru między milczeniem a mówieniem i w tym sensie jest to milczenie transcendentne (tamże). Nam taki rodzaj milczenia nie jest jeszcze dostępny. „Milczenie, które istnieje poza słowami. Milczenie to uwidacznia się 
w ludzkich postawach, łączy ludzi i jest wyrazem ludzkiej świadomości" (Niedziałkowski 1998, s. 19).

Ludzie są w większości uzależnieni od słów, którymi nie są w stanie wyrazić wielu uczuć. Milczenie jako świadoma rezygnacja z mowy może zobrazować te uczucia (tamże, s. 16). Gregory Bateson uznaje, iż „Nie można nie komunikować”. Oznacza to, że milczenie zawsze coś wyraża, coś komunikuje. Jest nośnikiem wielu znaczeń obecnych w kontekście pozajęzykowym i związanych z tym, kto milczy i wobec kogo to czyni (Rakoczy 2014, s. 460).

\section{... wokół diagnozy/rozpozania}

Choroba nowotworowa $\mathrm{u}$ dzieci $\mathrm{w}$ wielu przypadkach zaczyna się podstępnie i do właściwego rozpoznania dochodzi często po kilku tygodniach, a nawet miesiącach ${ }^{1}$. W tym czasie jeszcze nikt nie spostrzega niepokojących objawów i nie podejrzewa "trudnej” dla wszystkich przyszłości². Po ustąpieniu pierwszych dolegliwości, samopoczucie dziecka zaczyna nieco się poprawiać - jednak nie na długo. Wydaje się, że ponownie dziecko słabnie, boryka się z niedyspozycją ${ }^{3}$. Kontakt z lekarzem skutkuje pojawieniem się obaw i podejrzeń, którym towarzyszy szereg czynności diagnostycznych i często obfituje w „zmowę milczenia”. Jej źródłem są niekorzystne mity i uprzedzenia wiążące się z chorobą nowotworową. Zapewne ma ono swoje uzasadnienie ${ }^{4}$. Lekarz pierwszego kontaktu nie jest w stanie postawić ostatecznego rozpoznania, nawet jeśli ma głęboko uzasadnione podejrzenie. Takie rozpoznanie może być postawione tylko w wyspecjalizowanym ośrodku diagnostycznym. Jednak lekarz kierujący powinien wyjaśnić rodzicom, że celem skierowania jest wykonanie specjalistycznych badań pomocnych w wyjaśnieniu niecharakterystycznych objawów i dolegliwości. Jeśli rodzice domagają się więcej informacji, wówczas lekarz powinien wymienić im schorzenia brane

1 A. Chybicka pisze, że „Nowotwory rozwijają się z zasady podstępnie i nawet $\mathrm{w}$ zaangażowanym procesie często stan ogólny dziecka jest dobry. Wymaga to zachowania czujności onkologicznej przez lekarzy pierwszego kontaktu. Niezbędne są staranne badania fizykalne obejmujące całego małego pacjenta" (Chybicka 2009, s. IX).

2 Najczęściej rodzice zgłaszają się do lekarza rodzinnego z powodu w ich mniemaniu, stosunkowo łagodnych i typowych objawów, jak brak apetytu, infekcja, bóle kończyn (Kowalczyk, Samardakiewicz 1998, s. 37).

3 Wywiad prowadzony z rodzicami dzieci, u których rozpoznano ostrą białaczkę limfoblastyczną wskazuje na występowanie: apatii, osłabienia, skłonności do siniaczenia się pod wpływem błahych urazów, pokrwawienie z błon śluzowych jamy ustnej i nosa, powiększenie węzłów chłonnych obwodowych, postępującą bladość (Radwańska 1998, s. 57).

4 Autorzy zajmujący się problematyką choroby nowotworowej zarówno w wymiarze medycznym, jak i pozamedycznym twierdzą, iż przekazanie rodzicom informacji o rozpoznaniu powinno nastąpić po wykonaniu niezbędnych badań potwierdzających postawioną przez lekarzy hipotezę. Zatem czas diagnozowania i oczekiwania na wyniki wypełniony jest ciszą i milczeniem. 
pod uwagę, w tym chorobę nowotworową jako jedną z możliwości. Na tym etapie nie jest wskazane przedstawienie schorzenia nowotworowego, jako najbardziej prawdopodobnego rozpoznania, nawet wówczas, kiedy przemawia za tym wiele danych (Kowalczyk, Samardakiewicz 1998, s. 38).

Jeśli rodzice poznają przypuszczenia rozpoznania, wówczas zachowują milczenie wobec dopytującego się dziecka. Wokół chorego pojawia się zatem cisza.

Czas od otrzymania wyników do spotkania z lekarzem cechuje milczenie personelu pielęgniarskiego, który nie jest upoważniony do przekazywania informacji. Wielu rodziców chcąc jak najszybciej poznać diagnozę dopytuje napotkane osoby z personelu. Jednak pytania pozostają bez odpowiedzi. Zachowanie to jest jak najbardziej odpowiednie ${ }^{5}$, bowiem to na lekarzu spoczywa obowiązek informowania ${ }^{6}$. Lekarz spośród zawodów medycznych dysponuje najszerszą wiedzą medyczną i to on ma najszersze kwalifikacje do udzielania świadczeń zdrowotnych (Dercz, Izdebski, Rek 2015, s. 136).

Milczenie przerywa rozmowa w gabinecie kierownika kliniki. W czasie pierwszej rozmowy rodzice zwykle słuchają tego co ma do powiedzenia lekarz i czasem zadają pytania dotyczące przyczyn choroby, możliwości leczenia i wyleczenia dziecka. Lekarz po przekazaniu rodzicom rozpoznania zachowuje zwykle milczenie, które jednak nie jest oznaką tajemnicy i niemówienia. Wyraża zupełnie coś odmiennego. Jest oznaką współczucia. W tym milczeniu zawarte są najczęściej wszystkie jego emocje i szacunek dla powagi sytuacji (Bohdan 2011). Ten rodzaj milczenia, kiedy nie wypowiada się słów „pocieszania na siłę”, mogących zafałszować rzeczywistość, jest niezbędny w rozmowie z rodzicami. Warto w tym miejscu przypomnieć także słowa Bogdana de Barbaro (2005), który wskazuje, że $\mathrm{w}$ medycynie diagnoza jest kluczem do dialogu, porozumienia. Nie może być ona słowem zaklęciem wyłącznie dla wtajemniczonych. Nie powinna być zlepkiem niezrozumiałych słów. Lekarz w tym dialogu jest odpowiedzialny za umiejętne rozpoznanie intencji pacjenta (w przypadku dziecka najpierw są to rodzice), co on chce wiedzieć lub co należy mu przekazać. Diagnoza zatem może stworzyć relację lekarza z pacjentem.

Zupełnie inaczej sprawa może przedstawiać się w odniesieniu do dziecka. Pomimo jego prawa do informacji może ona do niego nie dotrzeć. Może zostać zatrzymana ze względu na ,jego dobro". Czasem milczenie, które jest wstrzymywaniem się od przekazania informacji, trwa "za długo", aż w końcu jest po prostu za późno (zob. Antoszewska 2007). Milczenie mające na celu dochowanie tajemnicy,

Pielęgniarka może udzielić pacjentowi lub jego rodzinie informacji o stanie zdrowia pacjenta w zakresie koniecznym do sprawowania opieki pielęgnacyjnej. Zob. Ustawa o zawodach pielęgniarki i położnej (art. 16, pkt 2) (Dercz, Izdebski, Rek 2015).

6 Podkreśla to ustawa o prawach pacjenta i Rzeczniku Praw Pacjenta, jak i ustawa o zawodach lekarza i dentysty. 
ukrycie prawdy, doprowadza do naruszenia zaufania, którym dziecko darzy rodziców.

Motywy milczenia zwykle biorą się z przerażenia, lęku jaki budzi choroba nowotworowa. Dla wielu rodziców nowotwór oznacza to samo co wyrok śmierci. Dla innych mówienie prawdy jest zadaniem ponad siły. Nie potrafią oni usłyszeć, o co pyta chore dziecko.

Kwestia informowania chorego dziecka powinna być uzależniona od tego czy ono chce wiedzieć, czy pyta na co jest chore i w końcu, czy mówi co chce wiedzieć. Jeśli milczy lub odmawia przyjęcia informacji o rozpoznaniu, nikt nie ma prawa $\mathrm{mu}$ ich przekazywać. W onkohematologii dziecięcej ustalono szereg rekomendacji dotyczących różnych etapów leczenia, wśród nich można odnaleźć te związane z informowaniem o rozpoznaniu choroby nowotworowej’. Podkreśla się w nich, iż najbardziej aktualnym pytaniem, jakie stawiają sobie lekarze onkolodzy i psycholodzy, jest to: „na ile i kiedy, w jaki sposób z taką diagnozą zaznajamiamy dziecko" (Kowalczyk, Samardakiewicz 2000, s. 732). Wiele lat wcześniej wyznawano zasadę nie informowania. Wskazywano, że dziecku nie jest potrzebna wiedza o naturze choroby i nie potrzebuje ono znać jej nazwy. Powinno jednak wiedzieć, że zaangażowanie w proces leczenia warunkuje jego wynik (Zdebska, Armata 1982). „Gdy rozpoznanie jest pewne, prawda musi być podana rodzicom, nigdy dziecku, i wytłumaczona w jasnych i zrozumiałych słowach, bez zbędnego wprowadzania ich w zawiłości lekarskiego myślenia" (tamże, s. 369-381).

Prowadzone badania i obserwacje wskazują, że przekazanie informacji wymusza kompleksowe wsparcie dziecka w trakcie choroby. Komitet Psychospołeczny SIOP przedstawia wiele propozycji, w jakich okolicznościach tę wiadomość przekazać otwierając w ten sposób możliwość wyboru najlepiej odpowiadającej opcji. Dziecko, u którego rozpoznano nowotwór, musi zrozumieć przyczynę, z powodu której jego życie w najbliższej przyszłości zostanie zmienione (Kowalczyk, Samardakiewicz 1998, s. 42).

„(...) Powiedział mi o biopsjach, guzach, kostniakomięsaku, remisjach. Moi rodzice słuchali go, ja robiłem notatki, cały czas notowałem. To dziwne, ale notując, poczułem się lepiej. To było tak, jakbym formułując pytania, zapisując je na kartkach, odzierał je z tajemnicy, strachu, grozy.

Kiedy lekarz skończyl, spojrzał na mnie i zapytał:

- Jakieś pytania?

Odpowiedziałem, że mam czterdzieści dwa. Tylko tyle zdążyłem zapisać. Tamtego dnia lekarz odpowiedział na moje czterdzieści dwa pytania, ale nasunęło mi się dwadzieścia kolejnych. Im więcej lekarz mi wyjaśniał, tym więcej miałem pytań, ale im więcej udzielał mi odpowiedzi, tym większy czułem spokój. To był taki cykl, korzystny zarówno dla mnie, jak i dla niego" (Espinosa 2015, s. 55-56).

7 Komitet Psychospołeczny Międzynarodowego Towarzystwa Onkologów Dziecięcych (Samardakiewicz, Kowalczyk 2000, s. 729-735). 
Zapewne nie można uniknąć momentów ciszy i milczenia zarówno w samym sposobie przekazywania informacji, jak i ich przyjmowania. Milczeniem, które z jednej strony może wyrażać szacunek wobec dziecka i jego trudnej, najbliższej przyszłości, jak i milczeniem związanym z ograniczonymi możliwościami języ$\mathrm{ka} /$ mowy (sytuacje dotyczące najmłodszych lub niepełnosprawnych intelektualnie pacjentów, choć zapewne nie tylko tych). Może się również pojawić milczenie związane z ograniczonymi informacjami, wiedzą o danym rodzaju nowotworu, jego możliwościach terapeutycznych, jak i milczeniem, w którym chory chce przeżyć diagnozę w ciszy.

\section{.... wokół leczenia}

W trakcie leczenia pojawiają się momenty, w których przez gardło rodzica nie przechodzą złe wiadomości. Chcąc "chronić" dziecko przed smutkiem, zapobiegać załamaniu, wycofaniu z leczenia rodzice nie przekazują wszystkich informacji pojawiających się $w$ trakcie leczenia. Dorośli starając się zrozumieć doświadczenia psychiczne dziecka z chorobą nowotworową wielokrotnie zapominają bądź przeceniają jego możliwości poznawcze i emocjonalne. Niedoceniają tego, że dziecko ma świadomość swojego stanu i sytuacji, w której się znajduje. Mają złudzenie, a często też nadzieję, że dziecko nie zdaje sobie sprawy z tego jak poważna jest jego choroba (Korzeniewska 1999, s. 34). Milczą.

Czasem bliscy muszą uczestniczyć długo w dramacie tajemniczości, przeżywając go bardzo boleśnie. Co więcej, często rodzina cierpi, ponieważ nie może w sposób otwarty dzielić swojego żalu z pacjentem (Strauss 1975) zwłaszcza, kiedy on nie chce rozmawiać lub jest za mały by podjąć rozmowę. Milczenie wokół chorego i cierpiącego dziecka wywołuje u niego poczucie osamotnienia.

Głównym rodzajem emocji, które towarzyszą dziecku choremu niezależnie od jego wieku, jest lęk. Jako że lęk dotyczy przede wszystkim sytuacji mało znanych lub nieznanych. Lęk może wyrażać się w pytaniach: Co się za mną stanie? Czy będzie mnie bolało? Co będzie się działo w trakcie zabiegu? Jak długo będę chorował? Czy wyzdrowieję? Brak jakichkolwiek informacji w obszarze kreślonych pytań może być przyczyną stosowania mechanizmów obronnych utrudniających adaptację do choroby (np. zachowania agresywne, regresja, ucieczka, wyparcie itp.).

Niekiedy - zdarza się to raczej rzadko - dzieci nie chcą rozmawiać o chorobie milczą. Nie mają ochoty, by ktokolwiek do nich mówił. Wolą przez jakiś czas być same. 


\section{.... wokół rodzeństwa}

Chore dziecko i jego rodzice to nie jedyne osoby, które odczuwają wpływ choroby nowotworowej. Do tej grupy zaliczyć należy zdrowe rodzeństwo, które także pyta o przyczynę i naturę choroby. Rozpoznanie choroby stanowi dla niego ogromne obciążenie. Pozostaje ono w wielu przypadkach $z$ dala od kliniki czy oddziału, w których prowadzone jest leczenie brata czy siostry. Problemy pojawiające się w obrębie wymienionej grupy zależą w dużej mierze od wieku dzieci zdrowych, poziomu ich rozwoju i wcześniejszych doświadczeń, a także od relacji jakie panowały w rodzinie (zapewne to nie są jedyne czynniki warunkujące pojawienie się problemów). Początkowo może dochodzić do odrzucenia faktu choroby u brata czy siostry, zazdrości o emocjonalną i fizyczną dostępność rodzica ${ }^{8}$. Zobrazowaniem trudnej sytuacji zdrowego rodzeństwa jest poniższa wypowiedź: „Wyobraź sobie, że masz osiemnaście lat, po szkole poszłaś na trening, właśnie pożegnałaś się z najlepszą przyjaciółką i wracasz do domu. Stajesz przed domem i zastanawiasz się: Dlaczego nigdzie nie pali się światło? Gdzie się podział samochód rodziców? Skąd takie uczucie pustki? Dlaczego nawet lampa na ganku nie jest zapalona?

Stajesz w korytarzu i słyszysz płacz w kuchni. Z ciemności wychodzi do ciebie jakiś obcy człowiek. Po chwili zdajesz sobie sprawę z tego, że to nie żaden obcy tylko pan Maguire, bliski przyjaciel rodziców. Podprowadza cię do kanapy, sadza i mówi, że twój młodszy brat jest w szpitalu. Ma białaczkę.

Powtarzasz sobie w kółko (...) To nie może być prawda. Czujesz się jak szmaciana lalka, którą za chwilę ktoś podniesie i zapewni, że wszystko będzie w porządku. (...) Zostajesz sama w pustym domu, żeby płakać... wyobrażać sobie najgorsze... i czekać, aż ta długa noc minie" (Bombeck 1995, s. 115-116).

Milczenie rodziców może spowodować u zdrowego rodzeństwa poczucie opuszczenia lub nawet odrzucenia, a także obwinianie siebie za chorobę brata czy siostry. Niekiedy pojawia się również obawa o życie chorego rodzeństwa, jak również o zdrowie własne i rodziców (Kowalczyk, Samardakiewicz 1998).

Osoby opiekujące się chorym rodzeństwem, a zwłaszcza rodzice powinni wyjaśnić zdrowym dzieciom ważne i nurtujące kwestie związane z chorobą (tamże). Kolejna wypowiedź wskazuje, w jaki sposób można przeprowadzić taką rozmowę. Nie jest ona receptą i regułą dającą się zastosować w każdym przypadku, jedynie pewną podpowiedzią. „Zbierałam się trzy dni, zastanawiając się, co mu powiedzieć. Próbowałam ocenić, co on chciałby wiedzieć. Pomyślałam, że powinniśmy najpierw spędzić przyjemnie czas, być tylko dla siebie. On czuł, że będzie

8 Szerszy opis sytuacji dotyczącej zdrowego rodzeństwa mającego chorą siostrę lub brata znajduje się w książce Kowalczyk, Samardakiewicz (1998). 
to coś poważnego: „Co się dzieje, mamo?" - „Markus jest bardzo chory" - „Jak bardzo?” - „Michael czy wiesz, co to jest rak?” - „Tak, mamo, ludzie mogą na to umrzeć." - „Markus ma raka, ale lekarze będą robić wszystko, by przezwyciężyć chorobę". Wyjaśniłam mu też, że taką chorobę bardzo trudno się leczy, że nikogo nie można np. przeciw niej zaszczepić. Początkowo strasznie się rozgniewał. Nie mógł zrozumieć, że lekarze są tacy "głupi". Chciał wiedzieć, skąd biorą się takie choroby, a tego nie umiałam mu wyjaśnić. Obiecałam jednak, że każdego dnia może pytać o samopoczucie Markusa. Wie, że czasem będę bardzo zmęczona (...), ale potem znajdę czas, by odpowiedzieć na wszystko" Pichler, Richter 1995, s.148).

\section{.... wokół rówieśników, kolegów, koleżanek}

Kolejną grupą, wokół której roztacza się bardzo często milczenie, są rówieśnicy chorego dziecka, koleżanki i koledzy z klasy. To milczenie zwykle jest spowodowane chęcią utrzymania choroby w tajemnicy, ukrywania jej ze względu na negatywne postawy i wciąż pokutujące stereotypy.

Przerwy w uczęszczaniu do szkoły mogą być bardzo częste, a ich długość zróżnicowana. Zależą najczęściej od rodzaju choroby nowotworowej, sposobu jej leczenia i reagowania dziecka na prowadzoną terapię, właściwości organizmu itp. W przebiegu tej grupy chorób dochodzi okresowo bądź trwale do zmniejszenia wydolności wysiłkowej dziecka, która może stać się obiektem zainteresowania rówieśników (np. ośmieszanie). Rozmowa z dziećmi to zadanie nauczyciela - wychowawcy czy psychologa, których rodzice poinformują o chorobie dziecka. Jej celem jest wykształcenie u rówieśników postawy życzliwości, zrozumienia i wzajemnej odpowiedzialności za siebie. Informacja o chorobie nie może być pozostawiona bez odpowiedzi na zadawane przez rówieśników pytania. Prawdziwa życzliwość i pomoc koleżeńska może zaistnieć tylko wówczas, kiedy choroba kolegi czy koleżanki nie będzie tematem tabu. Znajomość specyfiki choroby może przyczynić się do nawiązywania rozmaitych form kontaktu z chorym (listy, smsy, skype itp.), w okresach, w których kontakt bezpośredni jest uniemożliwiony.

Z badań wynika, że od $40 \%$ do $60 \%$ dzieci po przebyciu choroby nowotworowej cierpiało z powodu izolacji. Dość szybko zmniejsza się grono przyjaciól, koleżanek i kolegów, zanika ich przychylność, współpraca i zmniejsza liczba wspólnych zajęć. Nauczyciele niekiedy stwierdzają, że to "samotnicy”, „mali dorośli”. Powodów jest zapewne wiele. Czasem wynika to ze strachu przed ośmieszeniem, okazaniem mniejszej sprawności, ujawnieniem blizn pooperacyjnych itp. Czasem jednak rówieśnicy odrzucają dzieci po przebyciu choroby z obawy przed zarażeniem i zachorowaniem (zob. Owsiany 1996). 


\title{
.... w okresie stanu terminalnego
}

\author{
"Małe, niewinne, proste dziecie \\ Z lekkim oddechem w piersi, \\ Niedtugo żyło na tym świecie, \\ Cóż ono wie o śmierci? (...)" \\ William Wordsworth (2007, s. 67).
}

Jesteśmy uczestnikami powolnej, lepszej jakościowo zmiany nastawienia wobec umierających. Wyraża się ona w coraz szerszej dyskusji wokól przerywania zmowy milczenia, a ta jest niezbędnym warunkiem bardziej świadomej i dostosowanej do czasu umierania opieki. Idzie zatem o „przywrócenie śmierci godności” (Alichniewicz 1996, s. 145).

Śmierć dziecka jest trudna do zaakceptowania, a cóż dopiero proces powolnego umierania z powodu nieuleczalnej choroby. Pojawiają się wówczas pytania: Czy powiedzieć dziecku, że umiera? Jak to zrobić? A może nie mówić? Może najlepszym rozwiązaniem jest milczenie lub przekierowywanie tematu rozmowy na inny? Kto ma to zrobić?

Podjęcie decyzji o zakończeniu leczenia to szczególnie trudne doświadczenie dla wszystkich, którzy sprawują opiekę nad umierającym dzieckiem. Stawia personel medyczny w sytuacji, w której wiedza medyczna ustępuje miejsca doświadczeniu i umiejętności utrzymywania relacji oraz wspierającego komunikowania z dzieckiem i rodzicami (Kędzierska 2011). Sposób przekazywania wiadomości o tym, że dziecko umiera, jest szczególnym zadaniem. Jest to proces uwzględniający zarówno wsparcie emocjonalne, jak i informacyjne wykluczające zasianie fałszywej nadziei.

Milczenie, jakie mamy $w$ tym miejscu na myśli, związane jest z przemyśleniem sytuacji dziecka umierającego, rozpoznaniem czasu, w którym należy zakończyć leczenie agresywne i rozpocząć leczenie paliatywne. Milczenie to najpierw dotyczy lekarza wraz z całym zespołem medycznym sprawującym opiekę nad dzieckiem, a następnie jego rodziców. Kwestia jest delikatna i wymaga wyczucia, cierpliwości nie wspominając o wiedzy.

Niektórzy umierający chcą poznać prawdę i powołują się na prawo do niej, na godność człowieka. Inni natomiast przekazanie prawdy odbierają jako wyraz braku współczucia, empatii, wrażliwości. Trudno odpowiedzieć na pytanie, ile prawdy może przyjąć chory? Bowiem każdy człowiek jest inny i nie każdy jest przygotowany na zaakceptowanie śmierci.

To, czy umierające dziecko zdecyduje się na rozmowę o swojej chorobie lub nie, zależy od wcześniejszych i obecnych relacji w rodzinie. Dziecko może wybrać milczenie, ponieważ jego bliscy nie pozwalają rozmawiać o chorobie (nie chcą, nie 
są gotowi, nie potrafią) lub wprost przeciwnie, może otwarcie się komunikować, jeśli bliscy do tego zachęcają (za: tamże, s. 429). Cisza, która powstaje w pierwszym przypadku, może generować poczucie odrzucenia i izolacji, budować bariery pomiędzy dzieckiem a rodzicami (tamże). Milczenie może być wówczas kłamstwem osłoniętym "dobrem pacjenta", ochroną jego psychiki, które są wygodne dla wszystkich otaczających dziecko (np. lekarzy, rodziców). Umierającą osobę traktuje się jak chorą (zob. Alichniewicz 1996, s. 146). Anna Alichniewicz (1996, s. 146) zauważa, że postępowanie takie ma swoją konceptualizację - dwuznaczniki konwencjonalne. Są to wyrażenia, które na mocy konwencji nabierają w danej sytuacji innego znaczenia niż dosłowny i funkcjonują jako oczywiste dla wszystkich sposoby omijania odpowiedzi na pytania z różnych względów niewygodne.

B. Glaser i A. Strauss (zob. Zawiła 2008), dokonując analizy trajektorii umierania, wyróżnili konteksty świadomościowe, które zapewne można odnieść do sytuacji nie tylko śmierci, ale i choroby przewlekłej, nie tylko dorosłych, ale i dzieci.

1. "Zamknięty kontekst świadomościowy" - pacjent nie wie, że jest poważnie chory, ale wie o tym jego rodzina. Pojawienie się sprzymierzeńca wobec chorego może zmienić ten kontekst $\mathrm{w}$ inny.

2. "Kontekst otwartej podejrzliwości” - pacjent podejrzewa jaki jest stan jego zdrowia i różnymi sposobami stara się dociec prawdy. Jednak najbliżsi pełnią role strażników chroniących "owej tajemnicy".

3. "Kontekst wzajemnego udawania” - najstarszy. Obie strony wiedzą o chorobie, ale udają, że rzeczywistość jest inna. Kontekst może się zmienić wówczas, kiedy jedna strona postanawia "przerwać” milczenie.

4. "Otwarty kontekst świadomościowy" - to sytuacja, w której mówi się o chorobie otwarcie bez tabu. Zdaniem B. Glasera i A. Straussa jest najbardziej korzystna zarówno dla dziecka, jak i dla uporządkowania relacji, podtrzymania zaufania jakim dziecko darzy rodziców. Prowadzone badania wskazują, że najczęstszym argumentem przywoływanym przez rodziców, którzy zdecydowali się poinformować dziecko o chorobie, było jego zaufanie (Antoszewska 2006).

Kwestia „świadomości” ma zasadnicze znaczenie zarówno dla umierającej osoby, jak i osób sprawujących nad nią opiekę - tak medyczną, jak i pozamedyczną. Można oczekiwać także, że będzie ona odgrywała jeszcze większą rolę w drodze jaką pacjent przebywa między życiem a śmiercią (Strauss 1975). Kilkanaście lat temu generalną i powszechnie stosowaną zasadą była postawa utajania śmierci, głównie wobec osoby umierającej. Otoczenie dbało, by zablokowane lub opóźnione zostały informacje medyczne o zagrożeniu życia (Zuberek-Moskal 1999). Decyzja związana z utrzymaniem nieuleczalnie chorych dzieci w całkowitej niewiedzy o nadchodzącej śmierci podyktowana była przekonaniem, że jej 
uświadomienie wyrazi się w przyspieszeniu procesu umierania. Podłożem takiej strategii jest lęk tanatyczny (za: tamże, s. 272).

Nie ma jednoznacznych i doskonałych rozwiązań w trudnej emocjonalnie sytuacji, jaką jest zbliżająca się śmierć dziecka. Jednak prace badawcze, praktyka medyczna a szczególnie hospicyjna - wskazują, że zarówno u chorych dzieci, jak i chorych dorosłych występuje świadomość zagrożenia życia9. Dla wielu autorów problem świadomości nadchodzącej śmierci wśród dzieci chorych na nowotwory jest pytaniem o wiek, w którym owa świadomość się kształtuje. Jednak prace badawcze z omawianego zakresu wskazują, by z ostrożnością i rozwagą traktować wiek jako czynnik rozwoju świadomości zagrożenia śmiercią. Na rozwój jej mają bowiem wpływ inne istotne czynniki, do których należy zaliczyć doświadczenia dziecka z hospitalizacji, stopień zaawansowania choroby, stosowane metody terapii oraz zachowanie najbliższych i personelu. „Należy pamiętać, że dzieci poważnie chore dorastają szybciej niż ich zdrowi rówieśnicy i mogą wcześniej wykształcić w sobie pojęcie śmierci adekwatne do późniejszego etapu życia - w rozmowach mogą okazywać pełną świadomość swojej sytuacji, zagrożenia życia i dojrzale żegnać się z najbliższymi, zamykając swoje ważne sprawy" (Kostek 2015, s. 252). Nie mniej jednak zawsze warto zapoznać się z kształtowaniem się pojęcia śmierci u dzieci ze względu na wiek i wziąć je pod uwagę pracując z dzieckiem i jego rodziną. Wiedza ta pozwoli uniknąć pomyłek i często może przyczynić się do edukacji i poszerzenia wiedzy rodziców i innych dorosłych, którzy niekiedy mogą sądzić: „że dzieci o śmierci nie myślą i ona ich w ogóle nie dotyczy”10.

Jedną ze znanych teorii jest opracowanie M. Bluebond-Langer, która wskazała, iż nabycie wiedzy o chorobie odbywa się etapami współwystępującymi z narastającą patologią organizmu oraz stosowaniem coraz intensywniejszych zabiegów leczniczych. Dzieci chore doświadczając dolegliwości choroby, zachowanie personelu, zbierają informacje niezależnie od tego czy dorośli rozmawiają z nimi na temat choroby, czy nie (Kędzierska 2011). Bez względu na wiek, w początkowym etapie dziecko zdaje sobie sprawę z powagi sytuacji. Następnie doświadcza skutków ubocznych leczenia, rozumie cel zabiegów medycznych i stosowanej terapii. Kolejne etapy wskazują na pogorszenie stanu zdrowia, poprzez cykle nawrotów i remisji choroby, a także śmierć innego dziecka z oddziału. Wszystko to uświadamia choremu, że może umrzeć.

Unikanie rozmów na temat postępującej choroby i zbliżającej się śmierci wywołuje i podwyższa niepokój (Zuberek-Moskal 1999). Nie daje dziecku wspar-

9 Badania prowadzone przez Weatcher wskazują, że dzieci nieuleczalnie chore nie tylko ujawnily zdecydowanie wyższe wskaźniki lęku i niepokoju, ale także wykazały tendencję do stosowania kategorii śmierci, zagrożenia życia, choroby, bólu w otaczającej rzeczywistości (za: Zuberek-Moskal 1999, s. 273).

${ }^{10}$ Dokładnie opisane podziały wiekowe kształtowania się pojęcia śmierci u dzieci można odszukać w opracowaniu Rogiewicz, Tobota A. (2015, s. 426-430). 
cia. Ono jest bystrym obserwatorem wielu sygnałów zarówno werbalnych, jak i tych pozostających poza sferą werbalną (mimika, gesty, postawa ciała, ton i siła głosu itp.). Członkowie rodziny również nie potrafią stale udawać, są przecież samotni w swoim cierpieniu, niekiedy wyczerpani fizycznie i psychicznie (Antoszewska 2003). W takiej sytuacji łatwo zauważyć rozdźwięk pomiędzy przekazywanymi na siłę „dobrymi” informacjami a towarzyszącymi im emocjami. Pozostawienie pytań dziecka bez odpowiedzi skazuje je na samotność i bezsilność. Nie daje szansy na oswojenie lęku przed śmiercią - przed czymś czego i ono się boi. Umierające dzieci mają wiele problemów, które dorosłym wydawać się mogą błahe. E.N. Plank (zob. Leist 2004, s. 123) wskazała, że „(...) Jeśli nie pomożemy dzieciom w wyjaśnieniu tego co sobie wyobrażają, wówczas raczej wzmagają się lęki i fantazje na temat śmierci, aniżeli znikają zmartwienia". Czyż nie podobnie jest z młodzieżą i z dorosłymi? Czyż niewypowiedziane na głos problemy i zmartwienia nie narastają? Czyż nie pojawia się lęk, którego poziom z czasem jest coraz większy? Otóż na wszystkie powyższe pytania można odpowiedzieć twierdząco. Dziecko, młodzież czy dorosły w przedłużającej się samotności lub zbyt długo trwającej ciszy może doświadczać lęku. Aby nie zostawiać pacjenta bez pomocy w czasie zakończenia leczenia przyczynowego, należy przygotować się do tej bardzo ważnej rozmowy. Należy więc spytać dziecko/nastolatka:

- co wie już na temat swojej choroby,

- co sądzi na temat swojej choroby,

- co podejrzewa na temat swojej choroby,

- co naprawdę chciałoby wiedzieć,

- czy woli wiedzieć wszystko, czy niekoniecznie.

Dwa ostatnie pytania są najważniejsze, należy również pamiętać, że rozmowa ta powinna odbyć się w bezpiecznej atmosferze. Słownictwo i sposób rozmowy należy dostosować do wieku pacjenta i jego faz rozwojowych, a także wziąć pod uwagę również wspomniane kształtowanie się pojęcia śmierci u dzieci ze względu na wiek. Rodzina pacjenta i lekarz prowadzący powinni wiedzieć, co dziecko/nastolatek wie o swojej chorobie, jakich informacji dotyczących jego stanu i śmierci oczekuje. Ważne, aby po rozmowie z pacjentem psycholog/psychoonkolog poinformował prowadzącego lekarza o jego „woli”. Wówczas lekarz będzie wiedział, w jaki sposób poprowadzić rozmowę. Jeśli rodzic będzie nadal "chronił” dziecko (tak naprawdę „chroni” sam siebie przed wewnętrznym załamaniem), warto rozważyć z nim obecne i przyszłe skutki braku komunikacji z dzieckiem i udzielić mu wsparcia. Osobą pomocną w tej sytuacji będzie psycholog/psychoonkolog (Tobota 2015, s. 395).

Cisza wokół dziecka umierającego często powiązana jest z przerażeniem „nieodwołalnego wyroku" (Bohdan 2011, s. 142). Dzieci prawdopodobnie wiedzą o wiele więcej na temat postępującej w ich organizmie choroby, niż wykazują to 
wyniki i badania lekarskie. Rysując swoją chorobę pokazują, jak bardzo rozprzestrzenia się w całym ich organizmie, a medycyna potwierdza trafność tej wiedzy po śmierci dziecka (Leist 2011, 132). Podobnie twierdzi E. Kubler-Ross (2007), nadmieniając, iż dzieci, które ginęly w nieoczekiwanych, często dramatycznych okolicznościach, poruszały wcześniej temat śmierci w rozmowach z rodzicami.

Niejednokrotnie umierające dzieci pocieszają rodziców. Wprawdzie ze smutkiem, ale też i nadzieją godzą się na nadchodzące zmiany. Dzieci, które wychowywały się w poczuciu bezpieczeństwa, wierzą, że śmierć nie oznacza całkowitego osamotnienia i opuszczenia (Leist 2004).

Bardzo małe dzieci nie posiadają wiedzy na temat śmierci. Gdy umierają, to raczej dzieje się to bez lęku przed pożegnaniem na zawsze. $Z$ kolei u starszych w nagłych przypadkach zachorowań nie pojawia się bojaźń przed śmiercią. Jeszcze inaczej dzieje się, kiedy choroba jest długotrwała (tamże).

„Jakiekolwiek nie byłyby odmiany śmierci i obecność przy niej przyjaciół i krewnych, w każdym przypadku pozostaje ona wydarzeniem, które przeżywa się samotnie. Choćby nie wiem jak bliscy i aktywni byli inni, nigdy nie potrafią oni w pełni zrozumieć konającego, nawet jeśli towarzyszyli przy śmierci wielu innym osobom. Mogą być doświadczeni we współuczestnictwie, psychologicznie przydatni, bogaci uczuciowo, ale nigdy nie potrafią zmniejszyć nieodłącznej od śmierci samotności chorego. Każdy człowiek wobec tego wydarzenia jest sam (...)" (Leone 2000, s. 78).

Milczenie pojawiające się w okresie poprzedzającym śmierć może służyć refleksji nad własnym życiem, prowadzeniu dialogu z samym sobą, zastanowieniu się nad sensem wydarzeń. Krystyna Janda napisała: „Jestem szczęśliwa. Ale każdego dnia się szykuję do śmierci. Zrozumiałam, że umiera się łatwo. Mam poczucie, że śmierć może nadejść w każdej chwili. A nawet jestem pewna, że zaraz się zdarzy - dziś, jutro, pojutrze. Takie jest moje doświadczenie. Od jego śmierci czekam, którego to dnia. Robię sobie małe przyjemności, ale tak naprawdę się zbieram" (zob. Grzela 2015, s. 31).

Milczenie, które współistnieje z chęcią bycia z drugim człowiekiem, prowadzi do przewartościowania codziennych spraw.

\section{... wokół rodziny w żałobie}

Kolejna przestrzeń, w której często jeszcze spotykamy ciszę, to przestrzeń żałoby. Mamy tu na myśli przede wszystkim ciszę wynikającą z unikania, bagatelizowania problemów rodziny po stracie dziecka.

Pierwszym momentem ciszy i milczenia wokół rodziny jest organizacja pogrzebu zmarłego dziecka. Mamy wrażenie, że często nie mówi się o tym, jak on 
ma wyglądać, w czym pomóc rodzinie. Ceremonia pogrzebowa może być szczególnym wydarzeniem, jeśli umierający opowiedział o niej wcześniej. W ostatnich latach dzieci coraz częściej proszą o pozwolenie na jej przygotowanie. Szczególnie nastolatki chcą mieć określony strój, ulubioną muzykę. Te przygotowania wymagają aktywnej i otwartej postawy ze strony najbliższych (Kubler-Ross 2007). Ważne, aby próbować realizować ostatnie życzenia umierającego dziecka. Nie wypierać ich, nie bagatelizować, nie uciszać.

Jedną z okoliczności, która zasiewa ciszę i milczenie wokół rodziny po stracie dziecka, jest klimat społeczny, w którym śmierć stanowi temat tabu. Inne źródło milczenia wobec rodziny, która straciła dziecko, stanowią nasze błędne przekonania o tym czego ta rodzina potrzebuje, a czego na pewno jej nie potrzeba. Także i my często ochraniając siebie uciekamy od rozmów, twierdząc, że nie umiemy pomóc, jesteśmy bezradni. Owszem, tak rzeczywiście jest. Wobec śmierci każdy z nas pozostaje bez szans, nawet najbardziej uczony lekarz medycyny nie ma takiej wiedzy „,by odwrócić jej zamiar, powstrzymaćją w nieskończoność”. Wszyscy jednak możemy posiąść tę umiejętność, która wyraża się w towarzyszeniu słuchaniu i milczeniu.

W sytuacji żałoby pojawia się także cisza będąca poszanowaniem uczuć osieroconej rodziny. Wówczas wiele rzeczy dzieje się w milczeniu. Nikt się nie odzywa. Nie przeszkadza w ciszy, ale jest blisko, towarzyszy. Daje znak, że jest gotów pomóc.

$\mathrm{W}$ przestrzeni społecznej rozpoznanie potrzeb rodziny to istotna kwestia. Bowiem ona decyduje o udzielaniu jakościowo dostosowanej pomocy. Idzie o umiejętność różnicowania naturalnych reakcji żałoby od tych, które literatura nazywa patologiczną.

Często refleksja dotycząca udzielania pomocy rodzinie po śmierci dziecka przychodzi wówczas, kiedy sami jesteśmy taką sytuacją dotknięci lub mówią nam o tym rodziny, które przepracowały stratę.

Inny rodzaj milczenia związany jest z pominięciem woli rodziców dotyczącej umycia, ubrania i przygotowania zmarłego dziecka do pogrzebu. Wiele osób zapomina o tym, iż najbliżsi mają do tego prawo. Ten rodzaj milczenia może mieć negatywne konsekwencje w przeżywaniu żałoby.

\section{Zakończenie}

Artykuł nie omawia wszystkich kwestii związanych z tematem ciszy i milczenia, jakie pojawiają się wokół dziecka z chorobą nowotworową. Jest ich zdecydowanie więcej niż te, które zostały poruszone. Mamy nadzieję, że zaproponowany przegląd zainspiruje czytelnika do pogłębienia tematu. 
Kończąc powyższe rozważania warto zastanowić się nad konsekwencjami zastrzeżonej świadomości, o których pisał Anzelm L. Strauss (1975, s. 121), a które w nakreślonej sytuacji pojawiają się niemal we wszystkich zasygnalizowanych obszarach. Najistotniejszy jest jednak ten, który dotyczy samego dziecka - pacjenta. Autor postrzega go w dwóch kierunkach. Stan nieświadomości pacjenta - czyli ten wytworzony poprzez ciszę i milczenie związane z aktualnym stanem chorego - może przejść w stan uświadomienia. Może być też zupełnie odmiennie. Sytuacja zależy od warunków dochowywania owej tajemnicy, jak też od tych, które spowodowały jej ujawnienie. W sytuacji najmniej korzystnej - pacjent poczuje się oszukany, a w sytuacji przeciwnej do niej odczuje wdzięczność za opiekę i poszanowanie jego godności. Milczenie, w którym człowiek razem z nami świadomie wychyla się ku innej rzeczywistości i przeżywa jej bliskośćn jest milczeniem naturalnym i zdecydowanie różnym od zmowy milczenia (Prokulska 2004, s. 24).

Minimalizowanie przestrzeni milczenia na temat choroby nowotworowej nie tylko tej dotyczącej dzieci, ale i dorosłych - ma ważny wymiar. Mianowicie pozwala oswoić lęk przed chorobą (szybciej zgłaszać się do lekarza, podejmować leczenie itp.) i zmniejszać stygmatyzację osób nią dotkniętych (Samardakiewicz, Kowalczyk 2000, s. 729-735).

Z kolei pisanie, mówienie i czytanie o śmierci dzieci, młodzieży i osób dorosłych stanowi pierwszy ważny krok w zmianie spojrzenia na umierających, jak i sposobie opieki nad nimi i ich rodzinami.

„W porównaniu z nagłą i niespodziewaną śmiercią, choroba śmiertelna staje się „darem”, nawet mimo, iż z pewnością trudno jest - zwłaszcza jeśli przeżywana jest w cierpieniu - zrozumieć ją w tym ujęciu. Darem z siebie, który, jeśli przyjąć go i zinterpretować całą jego moc, staje się darem dla innych" (Leone 2000, s. 79). Czasem jednak trudno jest ten "dar" choremu i rodzinie przyjąć i zrozumieć. Dlatego jeśli ktoś potrzebuje takiej pomocy może skorzystać ze wsparcia specjalisty w tym zakresie, mamy tu na myśli psychologa/psychoonkologa, kapelana czy inne osoby z personelu medycznego, czy otaczającego chorego i jego rodzinę. Pozwoli to inaczej spojrzeć na zbliżającą się śmierć i docenić czas, który mamy na "przygotowanie" siebie i rodziny na pożegnanie i rozstanie.

„Śmierć, jako czas refleksji dla tego kto umiera, jest także czasem słuchania i nauki dla tego, kto pozostaje" (Leone 2000, s. 80).

\section{Bibliografia}

Alichniewicz A. (1996), Tanatologia filozoficzna jako podstawa tanatologii lekarskiej. "Twoja śmierć" $i$ "bycie-ku-śmierci" a sztuka dobrego umierania [w:] Umierać bez lęku. Wstęp do bioetyki kulturowej, red. M. Gałuszka, K. Szewczuk, Wydawnictwo Naukowe PWN. 
Antoszewska B. (2003), Opieka paliatywna wyzwaniem dla pedagogiki specjalnej [w:] Dyskursy pedagogiki specjalnej. Konteksty teoretyczne, red. E. Górniewicz, A. Krause, Wydawnictwo Uniwersytetu Warmińsko-Mazurskiego, Olsztyn.

Antoszewska B. (2006), Dziecko z chorobq nowotworowa, Kraków.

Antoszewska B. (2007), Dzieci i młodzież z choroba nowotworowa - wybrane zagadnienia [w:] Dziecko chore. Zagadnienia biopsychiczne i pedagogiczne, red. B. Cytowska, B. Winczura, Kraków, s. 188-190.

Bohdan Z. (2011), Czy cisza jest walorem czy klęska medycyny? (o medycznych aspektach ciszy) [w:] Dziecko przewlekle chore - problemy medyczne, psychologiczne i pedagogiczne, red. B. Antoszewska, Torun.

Bombeck E. (1995), Nic mi nie jest, po prostu miałem raka, Fundacja Pomocy Dzieciom z Chorobą Nowotworową, Warszawa.

Chybicka A. (2009), Wstęp [w:] Od objawu do nowotworu. Wczesne rozpoznanie chorób nowotworowych u dzieci, red. A. Chybicka, Elsevier, Wrocław.

Espinosa A. (2015), Świat na żótto. 23 małe odkrycia, które uratowaty mi życie, Kraków.

Grzela R. (2015), Obecność. Rozmowy, Warszawa, Drzewo Babel.

Kędzierska B. (2011), Dziecko wobec nieuleczalnej choroby i śmierci [w:] Pediatryczna opieka paliatywna, red. A. Korzeniewska-Eksterowicz, W. Młynarski, Uniwersytet Medyczny w Łodzi, Łódź.

Korwin-Piotrowska D. (2014), Stowo ibrak. Wybrane aspekty semantyki milczenia [w:] Milczenie. Antropologia-Hermeneutyka, red. A. Regiewicz, A. Żywiołek, Seria: od - głosy kultury, t.. 1, Częstochowa.

Korzeniewska J. (1999), Nikt nie wie, że wiem, „Magazyn Pielęgniarki i Położnej”, listopad.

Kostek M., (2015), Problemy psychologiczne w sytuacji rezygnacji z leczenia przyczynowego [w:] Praktyczny podręcznik psychoonkologii dzieci i nastolatków, red. M. Rogiewicz, Kraków.

Kubler-Ross E. (2007), Dzieci i śmierć. Jak dzieci i ich rodzice radza sobie ze śmiercia, Media Rodzina, Poznań.

Leist M. (2004), Dzieci poznają tajemnicę śmierci, Wydawnictwo Święty Wojciech, Poznań.

Leone S. (2000), Śmiertelnie chory, Wydawnictwo WAM, Kraków.

Niedziałkowski S. (1998), Świat mimu, Wydawnictwa Szkolne i Pedagogiczne, Warszawa.

Olearczyk T. (2010), Pedagogika ciszy, Wyższa Szkoła Filozoficzno-Pedagogiczna „Ignatianum" Wydawnictwo WAM, Kraków.

Prokulska B. (2004), Porozumiewanie się z terminalnie chorym [w:] Śmierć, „Zeszyty Formacji Duchowej", nr 24.

Przybyszewski S. (2012), „Mówić, milcząc. Nie milczeć, nie mówiąc”, „Prace Językoznawcze”, t. 14 , s. 237-248.

Radwańska U. (1998), Ostra białaczka limfoblastyczna [w:] Białaczki u dzieci, red. U. Radwańska, Volumed, Wrocław.

Rakoczy M. (2014), Wiedza a milczenie w edukacji wczesnoszkolnej - perspektywa antropologiczna [w:] Milczenie. Antropologia-Hermeneutyka, red. A. Regiewicz, A. Żywiołek A., Seria: od głosy kultury, t. 1, Częstochowa.

Regiewicz A., Żywiołek A. (2014), Milczenie. Od antropologii do hermeneutyki [w:] Milczenie. Antropologia-Hermeneutyka, red. A. Regiewicz, A. Żywiołek, Seria: od-głosy kultury, t. 1, Częstochowa. 
Samardakiewicz M., Kowalczyk J. (2000), Rekomendacje dotyczqce opieki psychospołecznej nad dziećmi z chorobami nowotworowymi, „Pediatria Polska”, t. LXXV, 9, s. 729-735.

Samardakiewicz M., Kowalczyk J. R. (1998), Dziecko z chorobą nowotworowa, Biblioteka Pediatry, Warszawa.

Rogiewicz M. (red.) (2015), Praktyczny podręcznik psychoonkologii dzieci i nastolatków, Wydawnictwo Medycyna Praktyczna, Kraków.

Rogiewicz M., Tobota A. (2015), Żałoba, w: Praktyczny podręcznik psychoonkologii dzieci i nastolatków, red. M. Rogiewicz, Kraków.

Tobota A. (2015), Rodzina w sytuacji rezygnacji z leczenia przyczynowego dziecka i nastolatka [w:] Praktyczny podręcznik psychoonkologii dzieci i nastolatków, red. M. Rogiewicz, Kraków.

Wordsworth W. (2007), Siedmioro nas jest, panie (We AreSeven), "Więź", listopad-grudzień.

Zawiła M. (2008), Religia i śmierć. Religia i śmierć. Trajektoria umierania i jej religijne elementy na przykładzie środowisk hospicyjnych w Polsce, Nomos, Kraków.

Zdebska S., Armata J. (1982), Psychologiczne problemy w nowotworowych chorobach krwi u dzieci [w:] Hematologia kliniczna wieku dziecięcego, red. M. Ochocka, PZWL, Warszawa, s. 369-381.

Zuberek-Moskal U. (1999), Rodzina w sytuacji wyznaczonej choroba nowotworowa dziecka [w:] Zmagając się z choroba nowotworowa, red. D. Kubacka-Jasiecka, W. Łosiak, Wydawnictwo Uniwersytetu Jagiellońskiego, Kraków. 